\title{
Association of SIRT5 gene expression with meat quality traits in F1 generation of wild boar $\times$ kele pig
}

\author{
Xiong ZHANG ${ }^{1}$, Jing ZHANG ${ }^{1 *}$, Jing WANG ${ }^{1}$, Chunping $\mathrm{ZHAO}^{1}$, Chunlin $\mathrm{DU}^{1}$, Kaizhi SHI ${ }^{1 *}$
}

\begin{abstract}
The aims of this study were to analyze the coding region sequence of the SIRT5 gene and to explore the association of SIRT5 gene expression with meat quality traits in the F1 generation of wild boar $\times$ Kele pigs (Yeke F1). In this study, two SNPs (g.5753 A > G, g.16916 A > G) were found in the CDS region of the SIRT5 that could affect meat quality. SIRT5 was an unstable hydrophilic protein with a highly conservative structure of the SIR2 functional domain. The expression of SIRT5 in subcutaneous fat was significantly higher than that of the longissimus dorsi muscle from Yeke F1 pigs $(P<0.01)$. The expression level of SIRT5 negatively correlated with meat color $(P<0.01)$ and positively correlated with the $\mathrm{pH}_{1}(P<0.05)$ in longissimus dorsi muscle. Expression of SIRT5 was positively correlated with meat tenderness, muscle moisture, heptadecanoic acid, elmintic acid and methyl nervonate $(P<0.01)$; however, it was negatively correlated with intramuscular fat content, myristic acid, stearic acid and trans linoleic acid $(P<0.05)$ in subcutaneous fat. This study indicated that SIRT5 could be used as a candidate gene for regulating intramuscular fat content and flavor indexes of Yeke F1 pigs.
\end{abstract}

Keywords: SIRT5; qRT-PCR; pork quality; fatty acids; correlation analysis.

Practical application: A candidate gene for pork quality.

\section{Introduction}

Different criteria are used to asses pork quality including the color of the meat, intramuscular fat or marbling, waterholding capacity (or drip loss) and fatty acid composition, all of which play an impotant role in the flavor of the final product. These pork quality traits have been linked to the expression of multiple genes including PHKG1(Zappaterra et al., 2019), PRKAG3(Ryan et al., 2012), FUT1 (Jiang et al., 2005), APOA5 and APOC3 (Hui et al., 2013). SIRT5 (Silence Information Regulator 5 ) is part of the Sirtuins family (Lombard et al., 2011; Yao et al., 2014; Simó-Mirabet et al., 2018) and has been associated with dessuccinylation, dipropionylation and glutarylation. Rardin et al. (Rardin et al., 2013) found that SIRT5 regulates the balance of fatty acid oxidation between mitochondria and peroxidase in mouse proximal tubular epithelial cells and participates in fatty acid oxidation in the body. Browning ability of subcutaneous white fat in SIRT5 knockout mice was impaired, which confirmed that SIRT5 is also a key factor in the differentiation of brown fat cells (Shuai et al., 2019). It has been demonstrated that SIRT5 can regulate fat deposition and meat quality traits in Qinchuan cattle (Deng, 2014). However, there is little research on the sequence and function of the SIRT5 gene in pigs, which is widely expressed in various tissues of Sujiang pigs, especially in the heart and liver (Wang et al., 2019).

Kele pigs are a high-quality breed native to Southwest China and the Guizhou Province, characterized by tolerance to extreme cold, humidity resistance, and stress resistance; the pig is also suitable for the complex breeding environment in Guizhou karst areas (Yang et al., 2019). Increased backfat thickness is one of the disadvantages that restrict Kele pigs from entering the international market. F1 generation commercial pigs were obtained by crossing Kele pigs with wild boars (Yeke F1). These animals maintain the excellent meat quality of Kele pigs as well as the low backfat thickness of wild boars, and their meat has high commercial value.

In view of the role of the SIRT5 gene in brown fat differentiation, fat deposition and meat quality traits of mammals. To further explore the relationship between the SIRT5 gene and pork quality performance indicators in Yeke F1 pigs, the coding sequence (CDS) region of the SIRT5 gene was obtained by cloning and its mutation sites were analyzed. The expression levels of SIRT5 in the longissimus dorsi muscle and subcutaneous fat of Yeke F1 pigs were detected by qRT-PCR, and their correlation with meat quality traits were analyzed, aiming to provide a foundation for understanding the regulation of the SIRT5 gene on pork quality and performance in the future.

\section{Materials and methods}

\subsection{Animals and sample collection}

Crossbred pigs (Kele pig $\odot \times$ wild boar ${ }^{\lambda}$ ) with average body weights of 100 to $120 \mathrm{~kg}$ at finishing ages of about 300 days were 
collected from local farms (Guizhou younonggu ecology industry co., ltd). All pigs were reared under the same conditions and fed the same commercial diet (Charoen Pokphand Group). Pigs were slaughtered, and then the carcasses were transferred to a cutting room. Longissimus thoracis et lumborum (LTL) muscle samples $(n=5)$ were collected from the left side of each carcass and used for meat quality analyses. The $\mathrm{pH}$, instrumental color, drip loss, cooking loss, Warner-Bratzler shear force (WBSF), muscle moisture content, and intramuscular fat (IMF) were assesssed on the same sampling day. The samples used for fatty acids were vacuum-packaged and stored at $-20^{\circ} \mathrm{C}$ until use. The longissimus dorsi and subcutaneous fat for gene cloning was stored at $-80^{\circ} \mathrm{C}$.

\section{2 pH measurements}

$\mathrm{pH}$ values of the pork samples were determined using a portable $\mathrm{pH}$ meter (Ohaus, USA) with a stainless steel and solidstate probe. Before use, the $\mathrm{pH}$ meter was calibrated with $\mathrm{pH} 4.0$ and 7.0 standards according to the manufacturer's instructions, and then the probe was inserted deep into the muscle tissue. The $\mathrm{pH}$ values of each sample were measured at $1 \mathrm{~h}\left(\mathrm{pH}_{1}\right)$ and $24 \mathrm{~h}\left(\mathrm{pH}_{24}\right)$ after slaughter, and the average of three readings was recorded.

\subsection{Instrumental color measurements}

Instrumental color traits were determined on 3 different locations of the freshly cut surface of each sample within $60 \mathrm{~min}$ of blooming using a CR- 400 colorimeter (Minolta Camera Co, Japan). Color is expressed according to the Commission International de l'Eclairage (CIE) system and reported as $\mathrm{L}^{*}$ (lightness), $\mathrm{a}^{*}$ (redness), $\mathrm{b}^{\star}$ (yellowness).

\subsection{Drip loss}

Drip loss of the muscle samples was measured following a procedure described in previous study (Fischer, 2007). Briefly, slices of standard thickness $(2 \mathrm{~cm})$ wer cut perpendicular to the fiber orientation within $2 \mathrm{~h}$. Each sample was assessed in triplicate. The slices were then suspended in an inflated sealed plastic bag, sealed in a refrigerator at $4{ }^{\circ} \mathrm{C}$, and removed after $48 \mathrm{~h}$. The weight of each sample before dripping $\left(\mathrm{W}_{1}\right)$ and after dripping $\left(\mathrm{W}_{2}\right)$ was weighed using an electronic analytical balance (Sartorius, German) and recorded. The drip loss of each sample was calculated as (Formula 1):

$\left(\mathrm{W}_{1}-\mathrm{W}_{2}\right) / \mathrm{W}_{1} \times 100 \%$

The drip loss value was the average of three repetitions.

\subsection{Cooking loss and Warner-Bratzler shear force value measurements}

Cooking loss and WBSF were measured on muscle samples $(3 \mathrm{~cm}$ thick, approximately $100 \mathrm{~g}$ ) cooked in a pre-heated water bath until the core temperature reached $70{ }^{\circ} \mathrm{C}$. The samples were then cooled in running water for $30 \mathrm{~min}$ to reach a core temperature below $30{ }^{\circ} \mathrm{C}$. Cooking loss was determined by calculating the difference in weight of the muscles before and after cooking and is expressed as percentage of initial weight. The cooking loss value of each sample reported herein is the average of three repetitions.

The same samples were used for WBSF analysis. Three cores of $2 \mathrm{~cm}$ in diameter were collected from each sample. WBSF values were obtained by completely cutting through the cores in an Instron Universal Testing Machine (Model 4465, Instron Corp, UK) using a crosshead speed of $200 \mathrm{~mm} / \mathrm{min}$ and a $40 \mathrm{~N}$ load cell.

\subsection{Chemical composition}

IMF content was measured using a Soxtec2055 automatic Soxhlet extractor (Foss, Denmark). Moisture content in the longissimus dorsi muscles was measured as described by Hoa et al. (Hoa et al., 2019).

\subsection{Fatty acid profiles}

Fatty acid profiles were determined as described below: Fats in samples were extracted using a solvent mixture of phenol:petroleum ether $(1: 1, \mathrm{v} / \mathrm{v})$. The extract was methyl esterified using potassium hydroxide-methanol solution ( $2 \mathrm{~mol} / \mathrm{L})$. Fatty acid composition was determined using a gas chromatography/flame ionization detector system (8860, Agilent Technologies, CA, USA). Fatty acids were separated on a DB-FastFAME $(30 \mathrm{~m} \times 0.25 \mathrm{~mm} \times$ $0.25 \mu \mathrm{M}$ film thickness; Agilent Technologies, CA, USA) at a split ratio of 100:1. Nitrogen was the carrier gas in constant pressure mode at 12.0 psi. A $2 \mu \mathrm{L}$ aliquot of each sample was injected into the injection port, and the temperatures of the injector and detector were set to $250^{\circ} \mathrm{C}$ and $260^{\circ} \mathrm{C}$, respectively. The oven temperature was kept at $80^{\circ} \mathrm{C}$ for $30 \mathrm{~s}$, raised to $165^{\circ} \mathrm{C}$ at a rate of $40^{\circ} \mathrm{C} / \mathrm{min}$, and further increased to $230^{\circ} \mathrm{C}$ at a rate of $4{ }^{\circ} \mathrm{C} /$ $\mathrm{min}$. The fatty acids in samples were identified by comparing their retention times to those obtained from standard fatty acids. The results are expressed as relative percentage (\%) of total fatty acids based on total peak area.

\subsection{RNA extraction and reverse transcription}

Total RNA was extracted using a RNAiso plus (Takara, Japan) from all samples, and the concentration and OD value (OD260 nm/OD280 nm = 1.8 2.0) were determined using an ultra-micro ultraviolet spectrophotometer (Thermofisher Ultrospec 2100 pro, USA). According to the instructions of the reverse transcription kit (Thermo Scientific RevertAidTM First Strand cDNA Synthesis; Thermofisher, USA), the total RNA of each sample was reverse transcribed, with the following reaction conditions: $42^{\circ} \mathrm{C}$ for $60 \mathrm{~min}$ and $75^{\circ} \mathrm{C}$ for $5 \mathrm{~min}$.

\subsection{Primer design and synthesis}

According to the GenBank porcine SIRT5 gene mRNA sequence (accessionNo.: NM_001105308.1), the internal reference gene is the porcine GAPDH gene (accessionNo.: NM_001206359.1). CDS region cloning and real-time fluorescent primers (Table 1) were designed using Primer Premier 5.0 and synthesized by Sangon Corporation. 
Table 1. Primer information.

\begin{tabular}{|c|c|c|c|c|}
\hline Gene & Primer sequence & Annealing temperature $/{ }^{\circ} \mathrm{C}$ & Fragment length/bp & Utilization \\
\hline \multirow[t]{2}{*}{ SIRT5-KL } & F: AACCTGATGCCACCTCTCTGG & 60 & 947 & CDS region clone \\
\hline & R: CGGGACGACTAAGAGACAGGTT & & & \\
\hline \multirow[t]{2}{*}{ SIRT5 } & F: CGTGGTCATCACCCAGAACA & 61 & 108 & qRT-PCR \\
\hline & R: GCTCCACAAGAGGTACACCG & & & \\
\hline \multirow[t]{2}{*}{ GAPDH } & F: TTGTGATGGGCGTGAACC & 61 & 169 & qRT-PCR \\
\hline & R: GTCTTCTGGGTGGCAGTGAT & & & \\
\hline
\end{tabular}

\subsection{Cloning and sequencing of the CDS region of SIRT5 gene}

PCR was peformed in a $20 \mu \mathrm{L}$ reaction mixture containing $10 \mu \mathrm{L}$ of $2 \times$ Taq PCR Master Mix (CW Biotech, China), $1 \mu \mathrm{L}$ of primers $(10 \mu \mathrm{mol} / \mathrm{L}), 1 \mu \mathrm{L} \mathrm{cDNA}$, and $7 \mu \mathrm{LddH}_{2} \mathrm{O}$. The reaction was run through pre-denaturation for $2 \mathrm{~min}$ at $94^{\circ} \mathrm{C}$; then run for 35 cycles of denaturation for $30 \mathrm{~s}$ at $94{ }^{\circ} \mathrm{C}$, annealing for $10 \mathrm{~s}$ at $60^{\circ} \mathrm{C}$, and extension for $30 \mathrm{~s}$ at $72^{\circ} \mathrm{C}$; followed by a final extension for $30 \mathrm{~s}$ at $72{ }^{\circ} \mathrm{C}$.

The PCR product obtained by the SanPrep column DNA gel recovery kit (Sangon, China) was purified and recovered by gel cutting and ligation with pCR2.1 vector (Thermofisher, USA). The ligation solution was transformed into DH5a (Takara, Japan). The qualified amplification products were sent to Sangon for sequencing.

\subsection{Quantitative real-time PCR}

A quantitative real-time PCR instrument (Bio-Rad CFX96, USA) was used to detect the expression of the SIRT5 gene, and the GAPDH gene was used as an internal control. Reaction conditions of qRT-PCR were as follows: $94^{\circ} \mathrm{C}$ for $2 \mathrm{~min} ; 94^{\circ} \mathrm{C}$ for $15 \mathrm{~s}, 61^{\circ} \mathrm{C}$ for $15 \mathrm{~s}, 72^{\circ} \mathrm{C}$ for $30 \mathrm{~s}, 40$ cycles. The amplification system was as follows: $2 \times$ Plus SYBR Real-time PCR mixture (CW Biotech, China) $10 \mu \mathrm{L}$, primers $0.5 \mu \mathrm{L}$, cDNA $1 \mu \mathrm{L}$, and $\mathrm{ddH}_{2} \mathrm{O} 8 \mu \mathrm{L} ; 3$ replicates per sample.

\subsection{Protein sequence analysis}

The physicochemical properties of the protein were analyzed using the Prot param (http://web.expasy.org/protparam/) program in the ExPASy online platform. Smart V6.0 (http:// smart.embl-heidelberg.de/) online software was used to analyze certain functional domains of the protein.

\subsection{Statistical analysis}

Pork quality traits and relative gene expression are expressed as mean \pm standard deviation. The relative gene expression obtained by real-time fluorescent quantitative PCR was calculated using the $2^{-\Delta \Delta \mathrm{Ct}}$ method. SPSS 18.0 software was used for $t$-test analysis for SIRT5 relative expression. The correlation between SIRT5 gene expression and meat quality indicators was analyzed by the Pearson correlation coefficient.

\section{Results}

\subsection{Cloning, identification and amino acid sequence analysis of SIRT5 gene from Yeke F1 generation pigs}

Electrophoresis on 1.2\% agarose gel (Figure 1) yielded a single well-specific cloned fragment (GeneBank No. MT149213), with a size of about $947 \mathrm{bp}$. The complete sequence of the CDS region of the SIRT5 gene of the Yeke F1 generation pig was $933 \mathrm{bp}$, encoding 310 amino acids in total, which was consistent with the expected target fragment size. Moreover, we found that there were nucleotide mutations at g.5753 A > G and g.16916 A > G in Yeke F1 pigs relative to the published sequence in GenBank. g.5753 A > G resulted in the change of lysine (Lys) to arginine (Arg), and the g.16916 A > G site was a synonymous mutation (Figure 2).

According to the analysis of the physical and chemical properties of the protein according to the amino acid sequence of SIRT5, the molecular formula of SIRT5 protein was obtained as follows: $\mathrm{C}_{1487} \mathrm{H}_{2344} \mathrm{~N}_{440} \mathrm{O}_{424} \mathrm{~S}_{14}$, the molecular mass is $33.6 \mathrm{kDa}$, theoretical isoelectric point is 8 , and instability coefficient is 48.32 , it belongs to unstable protein. The total average hydrophilicity is -0.193 , indicating that the SIRT5 protein is hydrophilic. Structural and functional domain analysis of SIRT5 protein showed that a highly conservative structural and functional domain SIR2 existed in the SIRT5 protein at positions 58-256 (Figure 3).

\subsection{Expression of SIRT5 gene in longissimus dorsi muscle and subcutaneous fat of Yeke F1 generation pigs}

With GAPDH as the internal reference gene, the relative expression of the SIRT5 gene in the longissimus dorsi of Yeke $\mathrm{F} 1$ generation pigs was $1.42 \pm 0.35$, and the relative expression in subcutaneous fat was $30.06 \pm 9.77$. The expression level of the SIRT5 gene in the subcutaneous fat tissue of the Yeke F1 generation pig is extremely significantly higher than that of the longissimus dorsi $(P<0.01)$ (Figure 4$)$.

\subsection{Correlation analysis between SIRT5 gene expression level and meat quality performance indicators}

The measurement results of the pork quality index of Yeke F1 generation are shown in Tables 2 and 3. Among them, the muscle moisture content of the Yeke F1 generation pig was $71.67 \%$, and the intramuscular fat was $3.26 \%$. Among the fatty acid composition indexes, the polyunsaturated fatty acid was $11.933 \%$. The correlation analysis between SIRT5 gene expression level and 
meat quality performance indicators is shown in Tables 2 and 3. Increased SIRT5 gene expression in the longissimus dorsi muscle was significantly correlated to the $\mathrm{pH}_{1}$ value $\left(\mathrm{R}^{2}=0.946, P<0.05\right)$ but significantly negatively correlated with $L^{*}\left(R^{2}=-0.994\right)$, $\mathrm{a}^{*}\left(\mathrm{R}^{2}=-0.994\right)$, and $\mathrm{b}^{*}\left(\mathrm{R}^{2}=-0.991\right)(P<0.01)$. The expression level in subcutaneous fat was negatively correlated with shear force $\left(R^{2}=-0.891\right)$, muscle water $\left(R^{2}=-0.89\right)$, and intramuscular fat content $\left(\mathrm{R}^{2}=-0.843\right)(P<0.05)$. The expression level of the

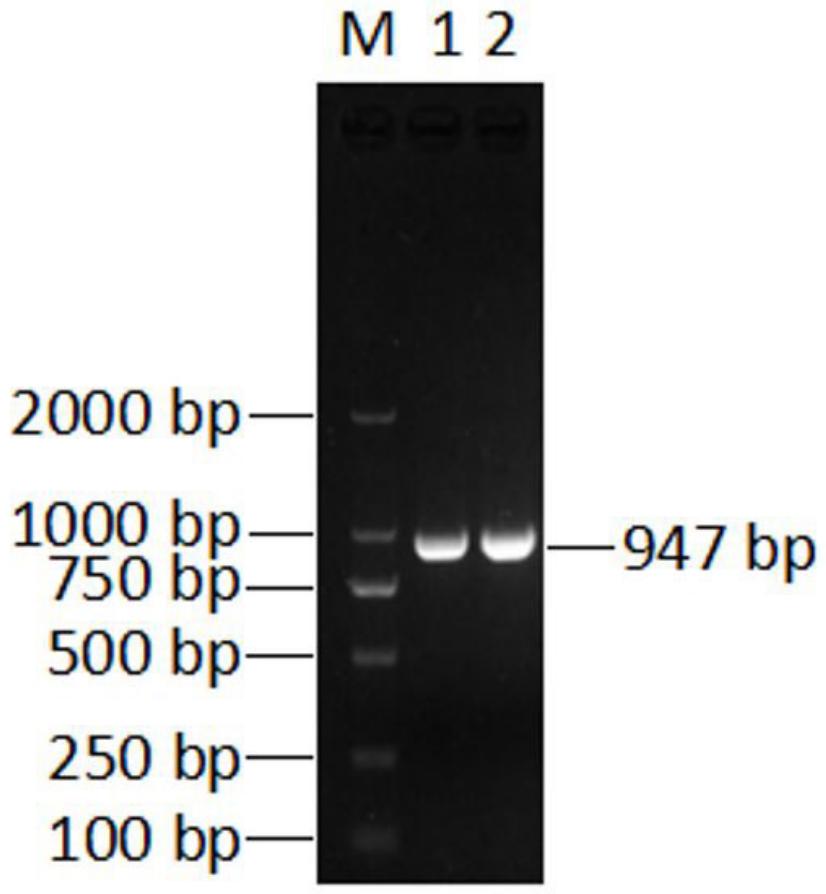

Figure 1. Amplification of SIRT5 gene in Yeke F1 pigs (M: DL2000 DNA marker; 1-2: Yeke F1 Generation).
SIRT5 gene in Yeke F1 longissimus dorsi muscle tissue is not related to fatty acid composition indexes, but the expression level of SIRT5 in subcutaneous fat is significantly negatively correlated with myristic acid $\left(\mathrm{R}^{2}=-0.906\right)$, stearic acid $\left(\mathrm{R}^{2}=-0.953\right)$ and Trans-linoleic acid $\left(\mathrm{R}^{2}=-0.889\right)(P<0.05)$, and significantly positively correlated with heptadecanoic acid $\left(\mathrm{R}^{2}=0.985\right)$, elmic acid $\left(\mathrm{R}^{2}=0.918\right)$ and methyl nervate $\left(\mathrm{R}^{2}=-0.936\right)(P<0.05)$.

\section{Discussion}

The SIRT gene family plays a critical role in the energy metabolism of the animal body, and the absence of SIRT5 can result in disorders in several metabolic pathways. Studies have shown that the SIRT5 gene can regulate fat deposition and meat quality in Qinchuan cattle (Gui, 2015). Comparing the sequence of the CDS region of the SIRT5 gene of the Yeke F1 generation pig with the Duroc pig revealed a mutation site (g.5753 A > $\mathrm{G})$ in the core protein domain of the Yeke F1 pig SIRT5 gene. When the SNP site occurs, mutations can cause changes in the amino acid sequence, affect the structure and function of the protein, and change the phenotypic traits of pig production. This study found that the expression levels of SIRT5 mRNA in the subcutaneous fat of Yeke F1 pigs was significantly higher than that in the longissimus dorsi muscle, indicating that the gene was expressed in subcutaneous fat with high white fat content in Yeke F1 pigs. The expression levels of SIRT5 in muscle tissue with high brown fat content is lower. It is speculated that this gene may be related to changes in the color of the pig fat and the process of pig fat deposition or fatty acid metabolism, which is consistent with previous reports in mice (Shuai et al., 2019).

To verify the correlation between the SIRT5 gene and pork quality traits, the correlation between the expression of the gene in the longissimus dorsi muscle, subcutaneous fat and the meat quality traits was analyzed. The SIRT5 gene expression level in the longissimus dorsi muscle correlates with meat color $\left(\mathrm{L}^{*}, \mathrm{a}^{*}, \mathrm{~b}^{*}\right)$ and $\mathrm{pH}_{1}$, indicating that SIRT5 can affect meat color and $\mathrm{pH}$ in muscle containing brown fat. Morever, SIRT5 gene expression was

\section{Yeke_F1 SIRT5 NCBI_SIRT \\ Yeke F1 SIRT5 NCBI ${ }^{-}$SIRT5 Consensus \\ Yeke F1 SIRT5 NCBI_SI RT5
Consensus \\ Yeke F1 SIRT5 NCBI_SIRTS Consensus \\ Yeke_F1_SIRT5 NCBI_SI RTS Consensus \\ Yeke F1 SIRTS NCBI_SIRTS Consensus Yeke_F1_SIRT5 Consensus Yeke_F1_SIRT5}

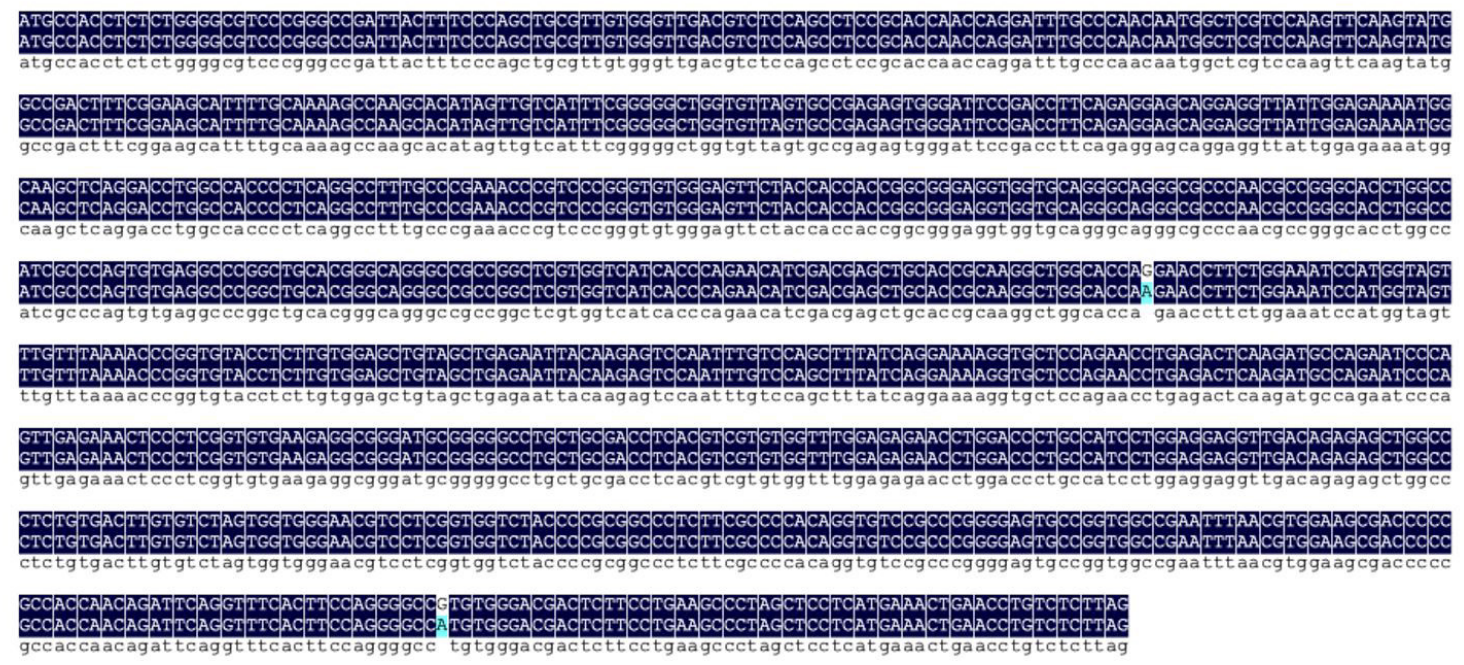

Figure 2. Sequence alignment diagram of SIRT5 gene sequence with public sequence in NCBI database. 


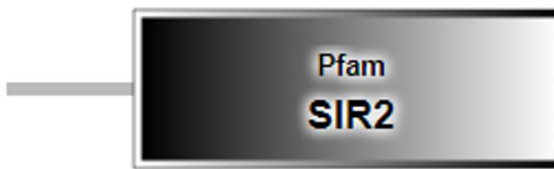

100

200

300

Figure 3. Prediction of the structural domain of SIRT5 protein in pigs.

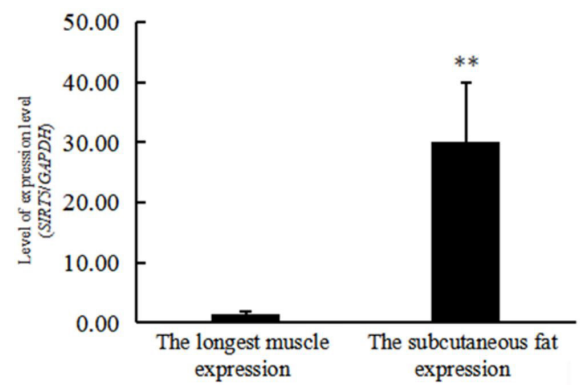

Figure 4. Expression analysis in the longest muscle and subcutaneous fat tissue of the SIRT5 gene in pigs. " indicates significant difference $(P<0.05) ;{ }^{*}$ indicates extremely significant difference $(P<0.01)$. positively associated with WBSF and muscle moisture content, and negatively associated with IMF in subcutaneous fat, which indicates that SIRT5 in subcutaneous fat can indirectly affect intramuscular fat deposition. This finding is consistent with the results that SIRT5 protein expression is negatively correlated with the abdominal fat content of Tongcheng pigs (Jin et al., 2009).

Fatty acids play an essential role in the composition of intramuscular fat. Fatty acids are carboxylic acids with a long aliphatic chain, which are divided into saturated fatty acids (SFA) and unsaturated fatty acids (UFA) (Khan et al., 2015). Results showed the expression of the SIRT5 gene in subcutaneous fat tissue to be correlated with four SFAs (C14:0, C17:0, C18:0 and C22:0), indicating that SIRT5 gene may influence the prone to oxidative rancidity of pig fat, affecting meat quality and shelf life(Nong et al., 2019). Increased levels of UFA improve meat quality, flavor and nutritional value. Many UFAs are precursors of meat flavor and have an essential impact on the formation of unique flavors of different breeds of pigs (Zhang et al., 2018). UFAs are divided into monounsaturated fatty acids (MUFA) and polyunsaturated fatty acids (PUFA). PUFA react to produce flavoring agents (including esters, ketones, and alcohols) when heated and react with other substances to determine meat flavor

Table 2. Pork quality traits and siginificant association of SIRT5 gene expression with pork quality traits index in Yeke F1 pigs.

\begin{tabular}{|c|c|c|c|c|}
\hline \multicolumn{2}{|c|}{ Traits } & Value & Longussimus dorsi & Subcutaneous fat \\
\hline \multicolumn{2}{|c|}{$\mathrm{PH}_{1}$} & $6.27 \pm 0.47$ & $0.946^{*}$ & 0.470 \\
\hline \multicolumn{2}{|c|}{$\mathrm{PH}_{24}$} & $5.61 \pm 0.65$ & -0.418 & 0.351 \\
\hline Instrumental color & $\begin{array}{c}\mathrm{L}^{*} \\
\mathrm{a}^{*} \\
\mathrm{~b}^{\star} \\
\text { Drip loss/\% } \\
\text { Cooking loss/\% } \\
\text { WBSF/kg.f } \\
\text { Moisture content/\% } \\
\text { IMF/\% }\end{array}$ & $\begin{array}{r}46.16 \pm 5.96 \\
7.86 \pm 1.53 \\
4.73 \pm 1.65 \\
3.36 \pm 0.37 \\
58.68 \pm 0.69 \\
6.81 \pm 2.94 \\
71.68 \pm 0.70 \\
3.26 \pm 0.94\end{array}$ & $\begin{array}{l}-0.994^{* *} \\
-0.994^{* *} \\
-0.991^{* *} \\
-0.631 \\
0.554 \\
0.624 \\
0.578 \\
-0.262\end{array}$ & $\begin{array}{l}-0.516 \\
-0.584 \\
-0.49 \\
0.123 \\
0.69 \\
0.891^{*} \\
0.889^{*} \\
-0.843^{*}\end{array}$ \\
\hline
\end{tabular}

"Indicates significant correlation $(P<0.05)$. ${ }^{* *}$ Indicates extremely significant correlation $(P<0.01)$.

Table 3. Fatty acid index content and siginificant association of SIRT5 gene expression with fatty acid index in Yeke F1 pigs.

\begin{tabular}{|c|c|c|c|}
\hline Fatty acid name & Content (\%) & Longus dorsi & Subcutaneous fat \\
\hline Myristic acid (c14:0) & $1.250 \pm 0.168$ & -0.389 & $-0.906^{*}$ \\
\hline Palmitic acid (c16:0) & $24.760 \pm 0.685$ & 0.029 & -0.685 \\
\hline XXVII carbonic acid (C17:0) & $0.133 \pm 0.014$ & 0.638 & $0.985^{\star *}$ \\
\hline Stearic acid (C18:0) & $11.015 \pm 0.724$ & -0.466 & $-0.953^{*}$ \\
\hline Eicosanoic acid (c20:0) & $0.227 \pm 0.021$ & -0.034 & -0.786 \\
\hline Elm Acid (C22:0) & $0.184 \pm 0.035$ & 0.275 & $0.918^{*}$ \\
\hline Palmitoleic acid (c16:1) & $3.665 \pm 0.131$ & -0.148 & 0.172 \\
\hline Heptadecanoic acid (c17:1) & $0.272 \pm 0.434$ & -0.352 & -0.768 \\
\hline Trans Oleic Acid (C18:1n9t) & $0.248 \pm 0.069$ & -0.142 & -0.561 \\
\hline Oleic Acid (C18:1n9c) & $45.825 \pm 0.662$ & 0.752 & 0.524 \\
\hline Eicosapentaenoic acid (C20:1n9) & $0.240 \pm 0.037$ & 0.423 & 0.102 \\
\hline Methyl nervonate (C24:1n9) & $0.246 \pm 0.060$ & 0.317 & $0.935^{*}$ \\
\hline Trans-Linoleic Acid (C18:2n6t) & $0.065 \pm 0.053$ & -0.565 & $-0.889^{*}$ \\
\hline Linoleic acid (c18:2nc6c) & $8.882 \pm 1.093$ & 0.088 & 0.824 \\
\hline Eicosadienoic acid (c20:2) & $0.351 \pm 0.046$ & -0.310 & -0.425 \\
\hline a-Linolenic Acid (C18:3n3) & $0.632 \pm 0.300$ & 0.402 & 0.663 \\
\hline Linolenic acid (C18:3n6) & $0.188 \pm 0.330$ & -0.291 & -0.737 \\
\hline Eicosatrienoic acid (C20:3n3) & $0.042 \pm 0.013$ & -0.424 & -0.376 \\
\hline Arachidonic acid (C20:4n6) & $1.652 \pm 0.597$ & -0.068 & 0.699 \\
\hline Docosapentaenoic acid (c22:5) & $0.122 \pm 0.039$ & -0.294 & 0.549 \\
\hline Saturated fatty acid (SFA) & $37.570 \pm 1.481$ & -0.247 & -0.866 \\
\hline Monounsaturated fatty acid (MUFA) & $50.497 \pm 0.467$ & 0.752 & 0.124 \\
\hline Polyunsaturated fatty acids (PUFA) & $11.933 \pm 1.539$ & 0.009 & 0.796 \\
\hline
\end{tabular}

Polyunsaturated fatty acids (PUFA)

${ }^{*}$ Indicates significant correlation $(P<0.05) .{ }^{* *}$ Indicates extremely significant correlation $(P<0.01)$. 
(Zhao et al., 2017). Cameron et al. (Cameron et al., 2000) found that the specific types of fatty acids affect flavor. Specifically, C18:2n6, C20:4n6 and C22:4n6 correlate with improved meat flavor. This showed that the expression of the SIRT5 gene in subcutaneous fat tissue showed a significant negative correlation with C18:2n6, indicating that the low expression level of the SIRT5 gene in pigs can enhance the flavor of meat; however, the specific regulation mechanism still needs to be further explored.

\section{Conclusion}

This study successfully cloned the 933 bp sequence of the SIRT5 gene CDS region from Yeke F1 generation pigs, which encodes 310 amino acids. There are two base mutation sites, of which the g.5753 A $>\mathrm{G}$ is a missense mutation, and the SNP site is in the core domain of the SIRT5 protein. The expression level of the SIRT5 gene in the longissimus dorsi muscle and subcutaneous fat tissue of Yeke F1 pigs correlates with improved meat quality traits. High expression of the SIRT5 gene was negatively corelated with IMF content and fatty acid composition in subcutaneous fat.

\section{Acknowledgements}

This study was supported by the Youth Fund of Guizhou Academy of Agricultural Science ([2018]79) and the Guizhou Science and Technology Department (QKHZC [2020]1Y031, QKHZC [2019]2274 and QKHZC [2017]2589).

\section{References}

Cameron, N. D., Enser, M., Nute, G. R., Whittington, F. M., Penman, J. C., Fisken, A. C., Perry, A. M., \& Wood, J. D. (2000). Genotype with nutrition interaction on fatty acid composition of intramuscular fat and the relationship with flavour of pig meat. Meat Science, 55(2), 187-195. http://dx.doi.org/10.1016/S0309-1740(99)00142-4. PMid:22061084.

Deng, G. (2014). SNPs detection of Sirt3 and Sirt5 genes in qinchuan cattle and their correlation with body size and meat quality traits. Yangling: Northwest A\&F University. In Chinese.

Fischer, K. (2007). Drip loss in pork: Influencing factors and relation to further meat quality traits. Journal of Animal Breeding and Genetics, 124(1, Suppl. 1), 12-18. PMid:17988246.

Hoa, V. B., Seong, P., Cho, S., Kang, S., Kim, Y., Moon, S., Choi, Y., Kim, J., \& Seol, K. (2019). Quality characteristics and flavor compounds of pork meat as a function of quality grade. Asian Australasian Journal of Animal Sciences, 32(9), 1448-1457.

Hui, Y. T., Yang, Y. Q., Liu, R. Y., Zhang, Y. Y., Xiang, C. J., Liu, Z. Z., Ding, Y. H., Zhang, Y. L., \& Wang, B. R. (2013). Significant association of apoa5 and apoc3 gene polymorphisms with meat quality traits in kele pigs. Genetics and Molecular Research, 12(3), 3643-3650. http://dx.doi.org/10.4238/2013.September.13.8. PMid:24085428.

Jiang, X. P., Liu, Y. G., Xiong, Y. Z., \& Deng, C. Y. (2005). effects of fut1 gene on meat quality and carcass traits in swine. Yi Chuan, 27(4), 566-570. PMid:16120579. In Chinese.

Jin, D., Tan, H. J., Lei, T., Gan, L., Chen, X. D., Long, Q. Q., Feng, B., \& Yang, Z. Q. (2009). Molecular cloning and characterization of porcine sirtuin genes. Comparative Biochemistry and Physiology.
Part B, Biochemistry \& Molecular Biology, 153(4), 348-358. http:// dx.doi.org/10.1016/j.cbpb.2009.04.004. PMid:19389481.

Khan, M. I., Jo, C., \& Tariq, M. R. (2015). Meat flavor precursors and factors influencing flavor precursors--a systematic review. Meat Science, 110, 278-284. http://dx.doi.org/10.1016/j.meatsci.2015.08.002. PMid:26319308.

Gui, L. (2015). SNP detection of seven genes in Sirtuins family and its correlation with growth and meat quality traits of Qinchuan beef cattle. Yangling: Northwest A\&F University. In Chinese.

Lombard, D. B., Tishkoff, D. X., \& Bao, J. (2011). Mitochondrial sirtuins in the regulation of mitochondrial activity and metabolic adaptation. Handbook of Experimental Pharmacology, 206, 163-188. http://dx.doi.org/10.1007/978-3-642-21631-2_8. PMid:21879450.

Nong, Q., Liu, J., \& Shan, T. (2019). Variety differences of fatty acid composition and regulation mechanism of fatty acid deposition in pork. Dong Wu Xue Bao, 6, 2507-2514. In Chinese.

Rardin, M. J., He, W., Nishida, Y., Newman, J. C., Carrico, C., Danielson, S. R., Guo, A., Gut, P., Sahu, A. K., Li, B., Uppala, R., Fitch, M., Riiff, T., Zhu, L., Zhou, J., Mulhern, D., Stevens, R. D., Ilkayeva, O. R., Newgard, C. B., Jacobson, M. P., Hellerstein, M., Goetzman, E. S., Gibson, B. W., \& Verdin, E. (2013). Sirt5 regulates the mitochondrial lysine succinylome and metabolic networks. Cell Metabolism, 18(6), 920-933. http://dx.doi.org/10.1016/j.cmet.2013.11.013. PMid:24315375.

Yang, R., Yan, Z., \& Lin, P. (2019). Study on the difference of Kele pork quality in different slaughtering stages. Heilongiiang Animal Husbandry and Veterinary, 007, 44-47. In Chinese.

Ryan, M. T., Hamill, R. M., O’Halloran, A. M., Davey, G. C., McBryan, J., Mullen, A. M., McGee, C., Gispert, M., Southwood, O. I., \& Sweeney, T. (2012). SNP variation in the promoter of the prkag3 gene and association with meat quality traits in pig. BMC Genetics, 13(1), 66. http://dx.doi.org/10.1186/1471-2156-13-66. PMid:22831392.

Shuai, L., Zhang, L. N., Li, B. H., Tang, C. L., Wu, L. Y., Li, J., \& Li, J. Y. (2019). Sirt5 regulates brown adipocyte differentiation and browning of subcutaneous white adipose tissue. Diabetes, 68(7), 1449-1461. http://dx.doi.org/10.2337/db18-1103. PMid:31010955.

Simó-Mirabet, P., Perera, E., Calduch-Giner, J. A., Afonso, J. M., \& Pérez-Sánchez, J. (2018). Co-expression analysis of sirtuins and related metabolic biomarkers in juveniles of gilthead sea bream (sparus aurata) with differences in growth performance. Frontiers in Physiology, 9, 608. http://dx.doi.org/10.3389/fphys.2018.00608. PMid:29922168.

Wang, L., Zhang, W., \& Cao, Y. (2019). Study on the expression and distribution of SIRT5 gene in sujiang pig tissues. Chinese Journal of Animal Husbandry, 55(06), 51-56. In Chinese.

Yao, Y., Yang, Y., \& Zhu, W. G. (2014). Sirtuins: nodes connecting aging, metabolism and tumorigenesis. Current Pharmaceutical Design, 20(11), 1614-1624. http://dx.doi.org/10.2174/1381612811319999 0513. PMid:23888968.

Zappaterra, M., Sami, D., \& Davoli, R. (2019). Association between the splice mutation g.8283c $>$ a of the phkg1 gene and meat quality traits in large white pigs. Meat Science, 148, 38-40. http://dx.doi. org/10.1016/j.meatsci.2018.10.003. PMid:30300804.

Zhang, J., Chai, J., Luo, Z., He, H., Chen, L., Liu, X., \& Zhou, Q. (2018). Meat and nutritional quality comparison of purebred and crossbred pigs. Animal Science Journal, 89(1), 202-210.

Zhao, J., Wang, M., Xie, J., Zhao, M., Hou, Li., Liang, J., Wang, S., \& Cheng, J. (2017). Volatile flavor constituents in the pork broth of black-pig. Food Chemistry, 226, 51-60. 